\title{
The status of prisoners of war before its regulation in international law on the example of Polish prisoners of war of the Grande Armée in Russian captivity (1812-1816)
}

The interest of historians in the issues of territorial-political transformations caused by the outbreak of the French Revolution and the Napoleonic wars increased at the end of the $20^{\text {th }}$ century and has continued to this day primarily due to the $200^{\text {th }}$ anniversary of these events. They were crowned with the commemoration of the Congress of Vienna. Its deliberations were preceded by the first Parisian peace concluded in May 1814 and completed by the other one set in the French capital in November 1815. The chronological frames scheduled for those dates were followed by preparations for the Congress, its continued deliberations, and the first key decisions initiated. Among them, there were no decisions related to the future of prisoners of war captured by the belligerents in the years preceding the final defeat of Napoleonic France. The State-Parties eventually agreed that this problem would be resolved in the form of bilateral agreements. Among them, the most important ones were concluded with Russia along with several European governments, the agreement between St. Petersburg and Paris being of key importance. In this context, it is worth adding that the agreements did not concern the thousands of Polish prisoners of war who remained in Russian captivity. ${ }^{1}$

Referring to the subject of the Congress of Vienna, historians usually focus on the revision of territorial and political changes caused by the outbreak of the French Revolution and the Napoleonic Wars, as well as on the principles of Continental order developed by leaders of the 16 countries. However, it should be remembered that, apart from these key findings, the European powers' representatives initiated the process of establishing international humanitarian law in

\footnotetext{
1 On the basis of the aggregate data available in the Russian State Historical Archives, it became possible to determine the nationality of 38,200 of the 44,800 prisoners surviving in February 1813 . In this group, Poles constituted 10,012 prisoners of war. The largest group were the French, whose number was set at 14,010 . The data was obtained and was first developed by: O. Sokolov, Bitwa dwuch impierij 1805-1812, Moscow 2012, pp. 632-633.
} 
the capital on the Danube River. Its first act was the Declaration on the Abolition of the Slave Trade of 8 February $1815 .^{2}$ The second one could have been the treatment of prisoners of war and the rules of repatriation discussed in the Congressional lobby. However, the deliberators did not attempt to go beyond the "customary law of war" and did not decide to formally regulate these issues in the international legal dimension, leaving it to the interested states.

Little is known about the procedure and the circumstances in which the 16 delegations participating in the Congress of Vienna reached a consensus on the limitation of the newly-established international humanitarian law in the "Declaration on the Slave Trade" and omitting the prisoner-of-war issue. We do not know whether this decision took place only during the proceedings in Vienna or at the preparatory stage for the conference. This second possibility is supported by the fact that already in the summer of 1814 , the Russians and the French had developed a bilateral agreement on the repatriation of Napoleonic prisoners of war.

Firstly, the postponement of the necessary decisions in this sphere for many decades resulted from the fact that Russia, opting for bilateral agreements on prisoners, could easily force other states to abandon plans to introduce provisions regarding prisoners into the proposed international humanitarian law. The decisive argument was the fact that the majority of the prisoners from the Grande Armée was located on its territory. ${ }^{3}$ Since they were under Russian jurisdiction, in essence Petersburg had a decisive voice regarding their future. It seems that for Alexander I this was a key factor in the whole matter. The consent to establish and consequently to extend the new international humanitarian law to the area of prisoners would mean to the Russians that they would lose the possibility to arbitrarily and unilaterally impose the repatriation of thousands of their citizens on France and its former allies, especially those of 1812. In St. Petersburg, no one was going to give up this excellent tool of exerting influence on the participants of the Congress of Vienna. There were many disputable issues, the resolution of which was possible according the Russians' intent due to, among other things, playing the "prisoners of war card". In such a sensitive matter as the repatriation of prisoners, Western European governments had to take into

\footnotetext{
2 Despite the adoption of the declaration, the institution of slavery continued. In the British colonies, slavery was finally discontinued in 1843, in French in 1848, and in others even later.

3 According to the latest estimations, the total number of prisoners of war from the Grande Armée taken prisoner by Russian in 1812 oscillated around 110,300. So, almost one in five soldiers who had crossed the border of the Russian Empire came to be captured. By mid-February 1813 , about 65,500 of them had died. Others, i.e. 44,800 vegetated, scattered across the territory of 48 guberniyas - S. Chomczenko, Dwunadiesiat' jazykow w russkom plenu. Nacyonalnyj sostaw wojennoplennych Wielikoj armii posle Otieczestwiennoj wojny 1812 goda [in:] Epocha napoleonowskich wojn: ludi, sobytija, idiei. Matieriaty XIII naucznoj konfieriencyi, Moskwa 2015, pp. 233 et al.
} 
account the reactions of public opinion in their countries. This was well obvious and used on the Neva. It cannot be ruled out that, for example in relations with Paris, St. Petersburg could have used the "prisoners of war card" for over 20 years. There were such indications, for example, on the level of Russian diplomatic activity. Skillfully dispensed by the Russian embassy, information on successive groups of French prisoners "forgotten" by the Paris government and found somewhere on the outskirts of Russia successfully compromised subsequent governments over the Seine and even more disintegrated the already unstable political scene. The last case of this type was recorded in 1837, when sensational reports about 2,000 Napoleonic prisoners forced to stay and live in Tobolsk and its surroundings appeared in the press. ${ }^{4}$ Paradoxically, such reports undermined the image of France more than of Russia. In the case of the latter, anti-humanitarianism, not only against prisoners, was the norm, and in the case of the former a discrediting sensation.

During the Congress of the Vienna, hardly anybody in Russia understood that (paradoxically) it was in the interest of Russia to introduce provisions on prisoners of war to international humanitarian law. After all, most of them were located in its area. Alexander I was getting his image damaged by applying to them incoherent and, consequently, difficult to enforce internal law instead of universally accepted standards. European public opinion was constantly shocked by press reports on the far from humanitarian treatment of prisoners of the Grande Armée. All this undermined the Tsar's reputation as a liberal on the throne of Russia.

Secondly, the abandoning of the formal regulation of the problem of prisoners of war in the legal and international dimension by the participants of the Congress of Vienna resulted from the fact that the governments of the victorious powers establishing the new geopolitical order in Europe seemed convinced that the decisions adopted in the Austrian capital would prevent for many decades the Old Continent from conflict on a scale like the one from the turn of the $18^{\text {th }}$ and $19^{\text {th }}$ centuries. Hoping for a long-lasting peace, it was not decided to establish international regulations relating to the treatment of prisoners of war. ${ }^{5}$

The general picture of the conditions resulting in the omission of regulations on prisoners of war in the international humanitarian law newly established by the Congress of Vienna encourages historians to learn the details of this case. However, it turns out that both individual Western European historiographies,

\footnotetext{
${ }^{4}$ Report on this subject officially denied by Prosper de Barante, then French ambassador in Petersburg - More: F. Houdecek, Le gouvernement de Louis XVIII et le retour des prisonniers de guerre français en Russie 1814-1816, "Napoleonica. La Revue", 2014, No 3, https://www.cairn.info/revue-napoleonica-la-revue-2014-3-page-45.htm [retrieved on 19.06.18].

5 The breakthrough in this respect was brought only by the following the Geneva Conventions $(1864,1906,1929,1949)$ and the Hague Convention of 1907.
} 
as well as Russian ones, have not paid attention to this problem to date. There are many publications devoted to the fate of Napoleonic prisoners of war of the Grande Armée, but none of them in its entirety refers to the issue raised above.

In this respect the situation is much worse in Poland. It turns out that apart from Marian Kukiel publishing many decades ago and a small group of contemporary historians, no one in our country has undertaken more extensive research on the fate of Polish prisoners of war from the Grande Armée in Russian captivity. Thus, there is a huge deficit of publications on the subject of Polish prisoners taken captive during Napoleon's expedition in 1812.

Thanks to Russian historians, it is already known that this information is collected both in central and provincial archives of that country. Due to financial reasons, access to them is difficult for most Polish historians. Therefore, in 2012, Russian researchers Boris Milovidov and Vitaly Bessonov, on the wave of the $200^{\text {th }}$ anniversary of the Great Patriotic War, made the first attempt to fill the gap in our knowledge on the subject by publishing several monographic articles. $^{6}$

The situation of Polish historiography omitting the subject of prisoners of war in the Napoleonic Wars for many decades is a derivative of not only earlier omissions but also the fiasco of a promising research project entitled "Polish prisoners of war in Russia 1812-1815" carried out in 2010-2014 by one of the 19th-century historians from Torun connected with Ośrodek Studiów Epoki Napoleońskiej [Center of Studies of the Napoleonic Era]. Its finalization became impossible due to the death of Andrzej Nieuważny ${ }^{7}$ managing the project. In addition, Mieczysław Wieliczko ${ }^{8}$ representing the academia of Lublin, Tomasz

6 W. Bessonov, B. Milovidov, Polskije wojennoplennyje Wielikoj Armii w Rossii w 1812 1814 gg., "Adjutant", 2012, No 10, http://adjudant. ru/captive/bes06.htm [retrieved on 19.06.18]; B. Miłowidow, Wojennoplennyje Polaki w Sibiri w 1813-1814 gg., [in:] Otieczestwiennaja wojna 1812 goda. Istoczniki. Pamiatniki. Problemy. Matieriały XV Mieżdunarodnoj naucznoj konfieriencyi (Borodino, 9-11 sientiabria 2008 g.), Możajsk, 2009, pp. 325-358.

7 The deceased historian left a few monographic articles devoted to Polish prisoners from the Grande Armée in Russian captivity. See: A. Nieuważny, Przeciw Napoleonowi? Rosyjski projekt utworzenia legionu polskiego w 1813 roku. [In:] W kraju i na wychodźstwie: księga pamiątkowa ofiarowana profesorowi Stawomirowi Kalembce w sześćdziesięciopięciolecie urodzin, Z. Karpus et al. (eds), Toruń-Olsztyn 2001, pp. 715-723; Idem, Polscy jeńcy w Rosji 1812-1815: stan badań. [In:] Apogeum polskich nadziei: 200-lecie kampanii rosyjskiej 1812 roku, M. Ochman et al. (eds),, Warszawa 2012, pp. 133-140; Idem, Polskie wojennoplennye w Sibiri 1812-1815 gg., [in:] Sibirica: istoria Polakow $w$ Sibiri $w$ issledowaniach polskich i rossijskich uczenych. Sbornik naucznyh trudow po itogam polsko-rossijskich naucznych seminarow, Warszawa - Pultusk, 1-15 sentabra 2012 g., I. Troak (ed.), Nowosibirsk, 8-22 oktabra 2012 g., Nowosibirsk 2013, pp. 165-181; Idem, Polscy jeńcy w Rosji 1812-1815 - co wiemy?, "Przegląd Historyczny", 2014, Vol. 105, No 4, pp. 585-600.

8 M. Wieliczko, Jeniectwo wojenne Polaków w Rosji w latach 1503-1918 - określanie problemu, Lublin 1998, pp. 312. 
Ślęczka of the University of Wrocław ${ }^{9}$ and the author of this paper affiliated at the University of Bialystok, ${ }^{10}$ incidentally, on the margins of their main research interests, have dealt with the prisoners of war issue.

The only way to find answers not only about the circumstances in which the decisions to leave the case of prisoners of war out from the initial regulations within the scope of the international humanitarian law were made in Vienna, but also about the consequences of the said omission for the group of thousands of Polish prisoners of war from the Grande Armée in Russian captivity, is to refer to source materials. It turns out that in the latter case the decision by the participants of the Congress of Vienna to make no attempt to develop common legal regulations for captive prisoners of war common to the international community was fraught with consequences.

These are fully confirmed by the example of Polish prisoners of war of the Grande Armée. Because of the Kingdom of Poland's status within imperial Russia, the process of their release from captivity was not typical. Its implementation was not based on an inter-state bilateral agreement, like for example between Russia and France, but was the effect of unilateral decisions taken in St. Petersburg after only formal (essentially technical) consultations with the authorities of the Kingdom of Poland. In addition to general information on this subject available in the literature, the details pertaining to the course of these consultations, as well as the details of many other matters, for example related to the repatriation of Polish soldiers from Siberia and the Caucasus region, are not known.

Thus, before Polish historians there is a task to reach for sources, and not only to the rich epistolary-memoir heritage left by several prisoners of war and political-military Polish, Russian or Western European decision-makers, but above all to still undiscovered Russian archival resources. ${ }^{11}$

Analysis of this documentation shows, inter alia, that, on 29 September $1812^{12}$ the commander-in-chief of the Russian army, Field Marshal Mikhail Ku-

\footnotetext{
9 T. Ślęczka, Rosja i jej mieszkańcy w oczach polskich jeńców wojennych XVII oraz początków XIX wieku, "Napis", 2007, No 13, pp. 109-125.

10 A. Miodowski, Status jeńców polskich w niewoli rosyjskiej w kontekście postanowień kongresu wiedeńskiego, [In:] Klasyczna i romantyczna. Nowa postać Europy po kongresie wiedeńskim, red. [D. Grinberg, M. Winograd], Białystok 2018, pp. 7-26. The published in the volume 16/2018 of "Białostockie Teki Historyczne" monographic article The status of prisoners of war before its regulation in international law on the example of Polish prisoners of war of the Grande Armée in Russian captivity (1812-1816) is an extended English version of the author's paper of 2015 included in the post-conference volume referred to above.

11 Key materials for the subject are: Rossijskij Gosudarstwiennyj Istoriczeskij Archiv [RGIA], fond 1409, op. 1, d. 656, part 1-2.

12 All the dates referring to the events in question which took place within the Russian Empire are given in accordance with the Julian calendar.
} 
tuzov, sent a letter to the head of the Ministry of War Prince Alexei Gorchakov in which he suggested applying to the Tsar for permission to send Polish prisoners of war to the Caucasus region, where he planned to form them into several regiments. ${ }^{13}$ The relevant circular was published on 22 October 1812. On the basis of this document, the head of the Ministry of Police, Sergey Viazhitinov, ordered the provincial authorities to direct Polish prisoners of war to a focal point at the foot of the Caucasus in the Georgiyevsk region. ${ }^{14}$

The next step on the way to the legal regulation of the status of Polish prisoners of war in Russia was the proposal of the Finance Committee of 9 December 1812 to cover the costs of maintaining this group of prisoners. Already in the first point, the Commission proposed that Poles should be assigned to regiments stationed in the North Caucasus, in Georgia, and Siberia. This proposal was justified, on the one hand, by emphasizing the benefits resulting from the reduction of the maintenance costs of prisoners, and on the other, by pointing to the benefits that the Russian army could have by reaching thousands of trained military Poles. Recognizing these arguments, Alexander I approved the submitted proposal on 29 December and several thousand Polish prisoners of war joined the ranks of the Russian army.

In preparation to implement the Tsar's will, Sergius Vidyzmin, in the ordinance of 14 January 1813, ordered the governor's authorities to prepare the name lists of Polish prisoners of war. ${ }^{15} \mathrm{He}$ informed Prince Alexei Gorchakov about his actions in a special letter dated 4 February 1813. It contained a reservation that by the time these lists would be drawn up, the Ministry of War should have ordered the commander-in-chief of the Russian army to refrain from relocating Polish soldiers to Georgiyevsk. ${ }^{16}$ In response to the request, Field Marshal Mikhail Kutuzov informed Prince Alexei Gorchakov that due to the epidemiological threat from 17 December 1812 the relocation of all prisoners (including Poles) had been suspended. The information provided by the commander-in-chief indicated that the relevant prohibition was renewed by order of 28 January 1813 stating in it that "all prisoners of war without exception should stay where they were at the time of the order until further instructions were given". ${ }^{17}$ The postponing of the execution of the Tsar's decision regarding the joining of Polish prisoners

\footnotetext{
13 Matieriaty po Otieczestwiennoj wojnie. Podrob. żurnat ischodiaszczich bumag Sobstw. kancelarii Gławnokomandujuszczego sojedinien, armijami gienierat-fieldmarszała Kutuzowa-Smolenskogo w 1812 g., Moskwa 1912, p. 359.

14 W. Bessonov, B. Milovidov, op. cit., http://adjudant.ru/captive/bes06.htm.

15 Gosudarstwiennyj Archiv Kałużskoj Obłasti [GAKO], fond 32, op. 19, d. 530, listok [hereinafter: li.] 45; RGIA, fond 1286, op. 2, d. 176, li. 33ob.

16 Rossijskij Gosudarstwiennyj Wojenno-Istoriczeskij Archiv [RGWIA], fond 1, op. 1, d. 2660, li. 31 .

17 GAKO, fond 32, op. 19, d. 530, li. 74.
} 
of war to the Russian regiments stationed in the North Caucasus, Georgia, and Siberia from the winter to the spring saved many lives.

However, it was constantly threatened. The greatest risks did not arise, paradoxically, due to the severity of the climate or epidemiological threat, but because of the bureaucratic chaos typical of Russia. Before it was forbidden to relocate the prisoners, before the appropriate letter of Sergei Viasmitinov reached Prince Alexei Gorchakov, the latter ordered on 15 January 1813 to direct the first group of Polish prisoners to the Siberian $29^{\text {th }}$ Infantry Division. Ultimately, they were to supply one of its regiments stationed in Ishim. ${ }^{18}$ In this context, the strengthening of the non-observed prohibition on the relocation of prisoners by order of the commander-in-chief of January 28, 1813 is less surprising.

Rescue for the Poles was brought not only by the order of Field Marshal Mikhail Kutuzov, but also by the intervention of the head of the Ministry of Police. Having realized the difficulties encountered in practically implementing the provisions regarding Polish prisoners, Sergius Wiazmitinov intervened on 21 January with Prince Alexei Gorchakov. The reaction of the Ministry of War was immediate. It ordered the suspension of advanced preparations to relocate subsequent groups of Polish prisoners to the regions of the North Caucasus, Georgia, and Siberia. ${ }^{19}$

However, it turned out that both power ministries were unable to control the processes that had been initiated much earlier. As a consequence, at the end of January, the ministerial officials were surprised by the information that a group of 19 Polish prisoners of war, sent in November 1812 from Saratov, had arrived at the foot of the Caucasus. The last much more numerous parties of Poles from this town before the suspension of the relocation process reached Georgiyevsk at the beginning of March 1813. According to the guidelines of the Ministry of War, 100 privates were incorporated into regiments stationed in Georgia and more than 248 officers were sent to the garrison service and in field regiments deployed in the North Caucasus..$^{20}$ The next group of 304 prisoners was sent from Voronezh on 6 March to the same regiments in the $19^{\text {th }}$ and $20^{\text {th }}$ divisions. ${ }^{21}$

The decision on the formal resumption of the relocation process was made in St. Petersburg on 4 March. Informing the Ministry of War about it, the Commander-in-Chief of Russian troops presented the schedule on the basis of which of the military Poles were to be sent to Georgiyevsk. In the first stage, they were to be prisoners of wars from the camps located in the Governorates of

18 RGWIA, fond 1, op. 1, d. 2660, li. 23.

19 Ibidem, li. 27-29.

20 W. Bessonov, W. Totfapushyn, Wojennoplennyje Wielikoj Armii w Saratowskoj gubiernii [in:] Problemy izuczenija istorii Otieczestwiennoj wojny 1812 g. Matieriały wsieros. naucz. konf., Saratow 2002, p. 167.

21 RGWIA, fond 1, op. 1, d. 2658, li. 49. 
Saratov, Vitebsk, Chernihiv, Moscow and Kostroma. The second stage involved reaching for prisoners in camps in the Governorates of Kiev and Tambow, the third one - the Governorates of Minsk, Tver, Kursk and Poltava, and the fourth one from the Governorates of Inflanty, Courland, Novgorod, Orlov and Smolensk. A total of 6409 privates were sent to Georgiyevsk from the prisoner-of-war camps in the mentioned Governorates. Within the fifth stage of the relocation initiated by the decision of 28 March another 926 privates were sent from prisoner-of-war camps in the Governorates of: Orenburg, Perm, Vyatka and Pskov. All of them went to the $29^{\text {th }}$ Division stationed in the Tobolsk Governorate. ${ }^{22}$

Polish prisoners of war from the Grande Armée were sent to Siberia and the Caucasus region not only to supplement field and garrison units, but also to reinforce the formation intended for engineering works. According to the reports sent to the Ministry of War, 500 Polish soldiers received such assignment after 1 August 1813. They worked under Cossack guards constructing fortifications created along the banks of the Terek River. Their individual daily pay was only 15 kopecks. ${ }^{23}$

Already on 9 October 1813, the then commander-in-chief of the Russian army in the Caucasus region, General Semyon Portnyagin, informed Prince Alexei Gorchakov that all Polish prisoners of war destined for service in the Caucasus region had reached their mother units. Only the arrival of approx. 3,000 prisoners assigned for service in engineering battalions was expected. Due to the approaching winter and the related suspension of fortification work, the general asked for permission to direct the soon-to-come Poles to the civil authorities of the Caucasian Governorate. According to the Russian commander, possible consent for such a solution could bring savings to the Ministry of War in the form of reduced provision costs, to be taken over by the governorate authorities. The latter would gain a low-paid working force for a few months. Gorchakov not only rejected this proposal, but also decided to change the original service assignment for 3,000 Polish military. In a letter of 21 November, he instructed to direct them as personnel supplements to the garrison of Vladikavkaz and Georgiyevsk, as well as to serve in field artillery units. ${ }^{24}$

As can be observed from the actions of Minister Gorchakov and General Portiagin, the Russian military authorities (just like the civil ones) did not have a coherent concept of "managing" the Polish military from the Napoleonic army. They were a specific group of prisoners of war. Most of them originated from areas that Russia acquired as a result of the Congress of Vienna or the so-called Western Governors (the Eastern Borderlands of the $1^{\text {st }}$ Republic of Poland). As

\footnotetext{
22 Ibidem, d. 2658, li. 89.

23 Ibidem, d. 2635, li. 32ob-33.

24 Ibidem, d. 2658, li. 240-244.
} 
a consequence of the lack of international regulations relating to the treatment of prisoners of war and the disclosure of Russian internal dilemmas regarding how to treat Polish prisoners taken in 1812, it had to be decided in St. Petersburg whether to recognize them as typical prisoners of war or rebellious Russian subjects who had joined the ranks of the enemy.

The matter was urgent and it was necessary to settle it in the shortest possible time. The civil and military administration more and more often turned to the central authorities asking how to respond to the collective applications of Polish prisoners of war imprisoned in their camps to issue relevant documents and consent to return to their family homes. The Committee of Ministers dealt with this matter only on 19 August 1813 and decided on the advice of the Minister of Police Sergey Vyazmitinov to ignore the conclusions about Polish prisoners and continue to direct them to the focal points in Georgiyevsk and Ishim in order to further dispose of garrison, field, and engineering services. ${ }^{25}$

Contrary to the intentions of Minister Vyazmitinov, the application of such an approach could not solve the problem. A few months later (11 November), at the request of Field Marshal Mikhail Kutuzov, this matter was discussed again at the Committee of Ministers. The commander-in-chief, citing the letter sent to him by the Governor of Grodno, requested in his name to decide as soon as possible about the future of prisoners from the Western Krai in the camps located in the Grodno and Wilno regions. The Committee of Ministers had to decide whether to allow volunteers who had enlisted in 1812 to serve in the Napoleonic ranks to return to nearby family homes or to send them to the ranks in Georgiyevsk and Ishim. In the end, the second of the options gained more support. The decision was universal, as it did not concern only prisoners of war from one province, but from all others. The governorate offices were notified of this decision on 22 January 1814 , and they implemented it in an uncompromising way. ${ }^{26}$

Not being able to be released from captivity and unwilling to serve in the ranks of the Russian army, many Polish prisoners of war directed to Georgiyevsk and Ishim decided to accept Russian serfdom. In the Siberian realities, making such decisions unexpectedly favored contact with Polish exiles from the time of the Confederation of Bar and the Polish-Russian war of 1792. The scale of this phenomenon can be realized by reading the report by General Grigory Glasenapp ${ }^{27}$ directed to the Ministry of War on 25 October 1813. From this letter we find out that the command of one of the battalions in the Tobolsk garrison convinced 115 Polish soldiers to submit and sign an oath for eternal servitude

\footnotetext{
25 RGIA, fond 1263, op. 1, d. 45, li. 193.

26 Ibidem, d. 48, li. 123ob-124.

27 This is Gen. Gregor Johann von Glasenapp from the Inflant (1751-1819).
} 
to Russia. By the end of the next year, 13 Poles from this garrison did the same thing. ${ }^{28}$ According to the findings of W. Biessonov and B. Milovidov, as many as $28 \%$ of Polish prisoners of war sent to serve in Siberian units and garrisons decided to take such a step. ${ }^{29}$ It can be presumed that this percentage would have been higher if not for the decision of the Ministry of Police. In the ordinance "On the rules of subjecting prisoners of war to Russian serfdom" issued on 19 August, there are provisions prohibiting the application of this regulation to Poles. This exclusion was confirmed by both the Commander-in-Chief and the Committee of Ministers in the recommendations to the August order sent on 4 August 1813 to governorate offices..$^{30}$

The Polish troops, unable to return to family homes after direct release from prisoner-of-war camps, were forced to use the "third way", i.e. to escape. The scale of this phenomenon shows how determined they were to avoid service in the Russian army. Many of those directed to Georgiyevsk attempted to escape through Georgia to Persia or Turkey. Reports on this subject were sent to the Minister of War's desk one after another. In one of them of 1 August 1813, information about the escape of 90 Polish soldiers was found. And although 85 deserters were captured after a few days, the author of the report, General Semyon Portnyagin, expressed his fear that when Poles would become aware of local ethno-topographical conditions, there would be definite desertions on a massive scale. The report indicated that the few who had escaped the raid had already reached Persia and sought contact with French diplomatic representatives at the shah's court. The information was provided by the British deputy in Tehran to the Russian command in the Caucasus. Concerned by the influx of Poles, he offered help in their capturing and organizing their return to the Russian side. ${ }^{31}$

Such a small percentage of successful Poles escaping through the Caucasian routes leading to Persia and Turkey resulted, among other things, from the fact that a certain part of the autochthonous population was actively cooperating with the Russians, handing the captured fugitives away to their Cossacks. However, this type of situation was relatively rare. Much more often, fugitives from the Russian army after being captured by local "hunters" were forced to stay and perform typically slave labor for their families. Even cases of trading captive soldiers were recorded with prices depending on their age, health condition and craft talents. ${ }^{32}$

28 RGWIA, fond 1, op. 1, d. 2658, li. 247 i 260.

29 W. Bessonov, B. Milovidov, op. cit., http://adjudant.ru/captive/bes06.htm.

30 GAKO, fond 32, op. 19, d. 530, li. 474 i 633.

31 RGWIA, fond 1, op. 1, d. 2961, li. 32.

32 Gosudarstwiennyj Archiv Stawropolskogo Kraja [GASK], fond 63, op. 1, d. 96, li. 1-3. 
Restricting control over the Polish soldiers forced to serve in the Russian army and their fear of being enslaved after being captured by locals led to limiting the scale and frequency of escapes. However, this did not mean breaking the resistance of former Napoleonic soldiers. Unable to escape, they sabotaged the military service imposed on them in the Russian ranks. The most common form of insubordination was the refusal of the oath to be faithful to the Tsar. Without its submission, they could not formally take active duty. This was the case, among others, regarding 166 Polish soldiers incorporated into a Kazakh infantry regiment. In order to break their resistance, it was decided to punish everyone with flogging and dispersal. Those who, despite the repression still refused to take oaths were directed, against regulations, for regular service without their submission. Due to the uniqueness of their status they were subject to a stricter discipline. Informed of the situation, the Ministry of War approved "emergency measures" applied to the resistant Polish military and cautiously ordered them to continue their service in fortresses away from the Persian and Turkish borders. ${ }^{33}$

Even these draconian remedies were not enough to tame the Poles and force them to remain loyal. Realizing that, the high command of the Russian troops in the Caucasus region demanded that Prince Gorchakov, Head of the Ministry of War, send all Polish prisoners from the Napoleonic army to Siberian units. The answer to this postulate was negative. According to the Ministry of War, the Russian army needed Polish soldiers both in the Caucasus and in Siberia. ${ }^{34}$

Only the intervention taken on 15 August 1813 by the omnipotent general Alexei Arakachiev, and, finally, with the Tsar brought changes in the directions to relocate Polish prisoners expected by the command. At the end of September, Prince Gorchakov was ordered to make subsequent parties of Polish prisoners of war refusing to serve in units stationed in the Caucasus region be directed to Siberia. ${ }^{35}$

Permanent confusion in the circles of the Russian bureaucracy caused by the incorporation of Polish prisoners into the Russian army prompted some of the Petersburg decision-makers to take action that would definitively deal with this problem, troublesome for many. The decisive voice belonged to the Tsar. In the circle of his associates at the beginning of 1814, the supporters of the release of Poles from prisoner-of-war camps and from forced service in the Russian army gained the advantage. Opponents of the solution, being in the minority and unable to block it directly, took steps aimed at proliferating bureaucratic obstacles to prevent its practical implementation.

\footnotetext{
33 RGWIA, fond 1, op. 1, d. 2658, li. 134.

34 Ibidem, d. 2961, li. 33ob i 42.

35 Ibidem, d. 2658, li. 205, 209, 210
} 
The heads of the central offices involved in the matter were informed about the decision of Alexander I favorable to the Polish military by General Arakcheyev. He did so on 23 January 1814, instructing the commander-in-chief and heads of the police and war departments to undertake appropriate preparations for the practical implementation of the will of the Tsar. ${ }^{36}$ It was not until 17 March that Minister Vyazmitinov submitted a concretised proposal for implementing the January decision to the Committee of Ministers. He suggested that the repatriation of Poles should take place in similar conditions and on the same routes as in the case of the French military and those of the allied forces who had participated in the war of 1812 against Russia. ${ }^{37}$ The prisoners from the Duchy of Warsaw and from Galicia were to return via the repatriation points located in Bialystok and Radziwiłłow in Volhynia. Those departing the Russian Empire were to be registered by name. In the case of the Poles, everyone released from captivity was also to indicate the place where he planned to settle after leaving the Tsars' state. Officials of the Ministry of Police, who were ordered to keep these census lists, would even obtain information on whether the captive planned to return to his own home or live with relatives. The documentation was planned to be systematically sent to Saint Petersburg to Minister Vyazmitinov so that he could personally monitor the course of Polish military repatriation..$^{38}$ It took several months to prepare such meticulous procedures before the first Polish prisoner of war could leave the camp in the beginning of July 1814..$^{39}$

Even more efforts required the preparation of the repatriation of Polish military forces incorporated into the ranks of the Russian army. The Minister of Police estimated the number of this group at about 7,000. Their return to the country had to be prepared in cooperation with the Ministry of War and the commander in chief. The military bureaucrats sought to call upon a Russian recruit to a vacancy before dismissing anyone from the service. In practice, until the moment of obtaining a "replacement", no Pole could count on demobilization. Exception was made for the 3,000 military workers working to build fortifications over the Terek River. Due to the seasonality of the works carried out there, they could be released from service in the autumn of 1814. Ministers Vyazmitinov and Gorchakov agreed on their issue in a binding manner. ${ }^{40}$

The prolonged search for recruits able to replace the Polish troops in the Caucasian and Siberian regiments in Russia prompted the Ministry of War to apply to the Tsar for an indefinite postponement in the implementation of the January

\footnotetext{
36 RGIA, fond 1409, op. 1, d. 656, cz. 2, li. 158.

37 Ibidem, fond 1263, op. 1, d. 58, li. 388.

38 W. Bessonov, B. Milovidov, op. cit., http://adjudant.ru/captive/bes06.htm.

39 RGIA, fond 1409 , op. 1, d. 657 , li. $127 \mathrm{ob}$.

40 Ibidem, fond 1263, op. 1, d. 58, li. 389-390.
} 
decision. After Prince Gorchakov had obtained this consent, ${ }^{41}$ it became clear that only prisoners remaining within the jurisdiction of the Ministry of Police would be able to be released from captivity immediately. General Arakcheyev was informed about these restrictions in the process of Polish repatriation in a letter sent on 10 April 1814.42

Only after almost a year, on 9 March 1815, the subject of the repatriation of Polish prisoners recruited into the Russian army returned to the Committee of Ministers. Despite the formal recognition that the condition concerning the full substitution of released Poles from the service by recruits had been fulfilled, no decisions were taken which would enable the actual implementation of the Tsar's will of 23 January 1814. Almost another year passed, when on 12 January 1816, at the same forum, the Russian ministers decided to definitively withdraw from repatriating Polish troops serving in Caucasian and Siberian regiments. ${ }^{43}$

The multiplication of official difficulties within the Russian bureaucracy served as a pretext to delay the execution of the Tsar's decision freeing Poles from captivity. The military and civilian Russian bureaucracy in a typical manner opposed the monarch who, in its opinion, treated his Polish subjects too favorably. Since the time of the Confederation of Bar and the military withdrawal of Russia against its participants, the state had usurped the right to treat Poles as their quasisubjects. The common view was that Russian borders reached where the Russian soldier managed to reach.

The attitude became even more apparent after the Congress of Vienna, when most of the Polish lands were formally under the jurisdiction of the Tsarist Empire. Under these circumstances, it is not surprising that after the decision to free Napoleonic prisoners of war from captivity, external enemies (French, Italians, Dutch, and Germans from individual Reich countries) were treated differently than Poles, regarded as internal enemies. In the opinion of the Russian elite, the Western Krai inhabitants, who joined the ranks of the Grande Armée, had betrayed their new state. The Kingdom's inhabitants, who had only been in the Russian state since 1815 , were accused a priori of disloyalty. Due to the fact that they could be surrounded with the halo of fighters for the freedom of Poland in their homeland, both of them, even by their very presence in the country, would generate too great risks for the Russian position in Central Europe. That is why the Russian bureaucracy did everything to minimize the use of the "Tsar's favour" and the possibility to repatriate out of captivity back to Polish lands.

\footnotetext{
41 Ibidem, li. 391.

42 Ibidem, fond 1409, op. 1, d. 656, cz. 2, li. 158-159.

43 Ibidem, fond 1263, op. 1, d. 92, li. 243.
} 
There would never have been such a situation as in the case of several thousand Polish prisoners of the Napoleonic army taken prisoner by the Russians if the participants of the Congress of Vienna had attempted to go beyond the "customary law of war" and decided to formally regulate these issues, i.e. to establish international humanitarian law regarding prisoners of war.

The status of prisoners of war before its regulation in international law on the example of Polish prisoners of war of the Grande Armée in Russian captivity (1812-1816)

Summary

Not much is known about the mode of debating or the circumstances in which the 16 delegations to the Congress of Vienna worked out a consensus on limiting the newly laid down international humanitarian law to the "Declaration on the Abolition of the Slave Trade" and on omitting the issue of prisoners of war. It is not known whether the said resignation occurred only during the meeting in Vienna or already at the preliminary stage before the conference. The latter option is supported by the fact that as early as summer 1814 the Russians and French had established a bilateral agreement on repatriation of Napoleonic prisoners of war.

The only way to find answers - not only about the circumstances in which the decisions to leave out the case of prisoners of war from the initial regulations within the scope of the international humanitarian law were made in Vienna, but also about the consequences of the said omission for the group of thousands of Polish prisoners of war from the Grande Armée in Russian captivity - is to refer to source materials. It turns out that in the latter case, the failure by the Congress of Vienna participants to attempt to provide common legal regulations for the international community regarding prisoners of war remaining in captivity bore serious repercussions.

Due to the status of the Kingdom of Poland within the boundaries of imperial Russia, the process of releasing Polish Grande Armée prisoners of war from captivity was not typical. Its implementation was not based on an inter-state bilateral agreement as was the case between Russia and France, but was an effect of unilateral decisions made in Petersburg upon merely formal (actually technical) consultations with the authorities of the Kingdom of Poland.

Key words: Napoleon's expedition to Moscow in 1812, Polish prisoners of war in Russia, Congress of Vienna 1814-1815 


\title{
Położenie jeńców wojennych przed uregulowaniem ich statusu w prawie międzynarodowym na przykładzie polskich jeńców z Wielkiej Armii w niewoli rosyjskiej (1812-1816)
}

\begin{abstract}
Streszczenie
Niewiele wiemy na temat trybu procedowania i okoliczności, w jakich 16 delegacji uczestniczących w Kongresie Wiedeńskim wypracowało konsensus w sprawie ograniczenia nowo stanowionego międzynarodowego prawa humanitarnego do „Deklaracji w sprawie handlu niewolnikami” i pominięcia kwestii jenieckiej. Nie wiemy czy ta rezygnacja nastąpiła dopiero podczas obrad w Wiedniu, czy też już na etapie przygotowawczym do konferencji. Za tą drugą ewentualnością przemawia fakt, że już latem 1814 r. Rosjanie i Francuzi wypracowali dwustronne porozumienie w sprawie repatriacji jeńców napoleońskich.

Zainteresowanym tą problematyką pozostaje odwołanie się do materiałów źródłowych i poszukiwanie $\mathrm{w}$ nich odpowiedzi na pytania nie tylko o uwarunkowania, w jakich podjęto $\mathrm{w}$ Wiedniu decyzję o nieuwzględnieniu sprawy jeńców w pierwszych regulacjach $\mathrm{z}$ zakresu międzynarodowego prawa humanitarnego, ale też odpowiedzi na pytania o konsekwencje tego zaniechania dla wielotysięcznej grupy polskich jeńców z Wielkiej Armii w niewoli rosyjskiej. Okazuje się, że w tym ostatnim przypadku rezygnacja przez uczestników Kongresu Wiedeńskiego z próby wypracowania wspólnych dla społeczności międzynarodowej regulacji prawnych odnośnie do pozostających $w$ niewoli jeńców wojennych była brzemienna w skutki.

$\mathrm{Z}$ racji na status Królestwa Polskiego w ramach imperialnej Rosji proces uwalniania z niewoli polskich jeńców z Wielkiej Armii nie był typowy. Jego realizacja nie przebiegała bowiem w oparciu o międzypaństwową umowę dwustronną, jak np. między Rosją a Francją, lecz stanowiła efekt jednostronnych decyzji podjętych w Petersburgu po zaledwie formalnych (w istocie technicznych) konsultacjach z władzami Królestwa Polskiego.
\end{abstract}

Słowa kluczowe: wyprawa Napoleona na Moskwę w 1812, polscy jeńcy wojenni w Rosji, Kongres Wiedeński 1814-1815

\section{Bibliography}

\section{Archive sources}

Rossijskij Gosudarstwiennyj Istoriczeskij Archiv, fond 1409 , op. 1 , d. 656 .

fond 1263, op. 1, d. 45, 48.

fond 1286, op. 2, d. 176. 
Rossijskij Gosudarstwiennyj Wojenno-Istoriczeskij Archiv, fond 1, op. 1, d. 2635. fond 1, op. 1, d. 2658. fond 1, op. 1, d. 2660. fond 1, op. 1, d. 2961.

Gosudarstwiennyj Archiv Kałużskoj Obłasti, fond 32, op. 19, d. 530.

Gosudarstwiennyj Archiv Stawropolskogo Kraja, fond 63, op.1, d. 96.

\section{Published sources}

Matieriały po Otieczestwiennoj wojnie. Podrob. zurnat ischodiaszczich bumag Sobstw. kancelarii Gławnokomandujuszczego sojedinien, armijami gienierat-fieldmarszała Kutuzowa-Smolenskogo w 1812 g., Moscow 1912.

\section{Book monographs}

Sokolov O., Bitwa dwuch impierij 1805-1812, Moscow 2012.

Wieliczko M., Jeniectwo wojenne Polaków w Rosji w latach 1503-1918 - określanie problemu, Lublin 1998.

\section{Monographic articles in journals}

Nieuważny A., Polscy jeńcy w Rosji 1812-1815 - co wiemy?, "Przegląd Historyczny" 2014, t. 105 , z. 4 , pp. 585-600.

Ślęczka T., Rosja i jej mieszkańcy w oczach polskich jeńców wojennych XVII oraz początków XIX wieku, "Napis" 2007, No 13, pp. 109-125.

\section{Monographic articles in collective works}

Biessonow W., Totfapuszin W., Wojennoplennyje Wielikoj Armii w Saratowskoj gubiernii [in:] Problemy izuczenija istorii Otieczestwiennoj wojny 1812 g. Matieriały wsieros. naucz. konf., Saratov 2002.

Chomczenko S., Dwunadiesiat' jazykow w russkom plenu. Nacyonalnyj sostaw wojennoplennych Wielikoj armii posle Otieczestwiennoj wojny 1812 goda [in:] Epocha napoleonowskich wojn: ludi, sobytija, idiei. Matieriały XIII naucznoj konfieriencyi, Moscow 2015.

Miłowidow B., Wojennoplennyje Polaki w Sibiri w 1813-1814 gg., [in:] Otieczestwiennaja wojna 1812 goda. Istoczniki. Pamiatniki. Problemy. Matieriały XV Mieżdunarodnoj naucznoj konfieriencyi (Borodino, 9-11 sientiabria 2008 g.), Mozaysk, 2009, pp. 325-358. 
Miodowski A., Status jeńców polskich w niewoli rosyjskiej w kontekście postanowień kongresu wiedeńskiego, [W:] Klasyczna i romantyczna. Nowa postać Europy po kongresie wiedeńskim, red. [D. Grinberg, M. Winograd], Białystok 2018, s. 7-26.

Nieuważny A., Przeciw Napoleonowi? Rosyjski projekt utworzenia legionu polskiego w 1813 roku, [in:] W kraju i na wychodźstwie: księga pamiatkowa ofiarowana profesorowi Sławomirowi Kalembce w sześćdziesięciopięciolecie urodzin, Z. Karpus et al. (eds), Toruń-Olsztyn 2001, pp. 715-723.

Nieuważny A., Polscy jeńcy w Rosji 1812-1815: stan badań [in:] Apogeum polskich nadziei: 200-lecie kampanii rosyjskiej 1812 roku, M. Ochman et al. (eds), Warszawa 2012, pp. 133-140.

Nieuważny A., Polskie wojennoplennye w Sibiri 1812-1815 gg., [in:] Sibirica: istoria Polakow $w$ Sibiri $w$ issledowaniach polskich i rossijskich uczenych. Sbornik naucznyh trudow po itogam polsko-rossijskich naucznych seminarow, I. Troak (ed.), Warszawa - Pultusk, 1-15 sentabra 2012 g.; Novosibirsk, 8-22 oktabra 2012 g.; Nowosibirsk 2013, pp. 165-181.

\section{Monographic articles online}

Biessonow W., Miłowidow B., Polskije wojennoplennyje Wielikoj Armii w Rossii w 1812 1814 gg., "Adjutant” 2012, No 10, http://adjudant.ru/captive/bes06.htm.

Houdecek F., Le gouvernement de Louis XVIII et le retour des prisonniers de guerre français en Russie 1814-1816, "Napoleonica. La Revue" 2014, No 3, https://www.cairn.info/revue-napoleonica-la-revue-2014-3-page-45.htm 